\title{
Working hours spent on repeated activities and prevalence of back pain
}

\section{H-R Guo}

See end of article for author's affiliation

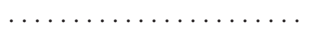

Correspondence to: Dr H-R Guo, Graduate Institute of Environmental and Occupational Health, Medical College, National Cheng Kung University, 138 Sheng-Li Road, Tainan 70428, Taiwan;

hrguo@mail.ncku.edu.tw

Accepted 10 April 2002
Background and Aims: Back pain is the most common reason for filing workers' compensation claims in the United States and affects large numbers of workers in many other countries. To evaluate the associations between working hours spent on repeated activities and back pain, data gathered through the 1988 National Health Interview Survey were analysed. The data were also used to identify high risk occupations.

Methods: A total of 30074 workers participated in the survey. They were asked to provide information on their job, including the time spent on repeated strenuous physical activities (RSPA) and the time spent on repeated bending, twisting, or reaching (RBTR) on a typical job. A case of back pain was defined as a worker who had back pain every day for a week or more during the past 12 months. Each case was asked to report the cause of back pain. Those who attributed their back pain to repeated activities (RA) or a single accident or injury (Al) were asked to recall whether they performed RA or had the Al at work.

Results: Whereas the prevalence of back pain increased as the number of working hours spent on RSPA or RBTR increased, the dose-response relations were not linear for either factor, suggesting the involvement of other unmeasured factors. The estimated overall prevalence of RA back pain was $8.9 \%$ among male workers and $5.9 \%$ among female workers. "Carpenters" had the highest prevalence $(19.2 \%)$ and most cases $(338000)$ among the major occupations of men, and "nursing aides, orderlies, and attendants" had the highest prevalence (15.2\%) and most cases (217 000) among the major occupations of women.

Conclusions: The number of hours spent on repeated activities at work was associated with the prevalence of back pain. This study identified high risk occupations for future research and intervention.
$\mathrm{B}$ ack pain is the most common reason for filing workers' compensation claims in the United States and accounts for about one quarter of all claims. ${ }^{12}$ However, because the compensation for back pain is generally above the average, about one third of total compensation is paid for back pain claims. $^{3}$ After the common cold, back pain is the second most common cause of sickness leave and accounts for about $40 \%$ of sick absences from work. ${ }^{3}$ The total cost of back pain in the United States was estimated to be 50-100 billion dollars in $1990 .{ }^{4}$ Back pain also affects many workers, leads to large numbers of lost workdays, and results in huge economic loss in many other countries. ${ }^{5-12}$

Although the social and economic impacts of back pain are huge, the amount of data and research efforts to address the problem at the national level has been limited. Only a small number of nationwide studies on back pain have been conducted, and most were unable to indicate specific occupational risk factors. ${ }^{124^{13-15}}$ In 1988, an Occupational Health Supplement was included in the National Health Interview Survey (NHIS), a personal interview survey conducted annually by the National Center for Health Statistics (NCHS). An analysis of the data gathered through this survey estimated that there were about 22.4 million cases of back pain among workers in the United States in 1988 who lost a total of about 149.1 million workdays. ${ }^{16}{ }^{17}$ Because a large proportion of the cases and the lost workdays were attributable to activities at work, ${ }^{16}$ further analyses of the data were conducted to evaluate the association between the number of working hours spent on repeated activities at work and work related back pain. In addition, the analyses aimed to identify high risk occupations of back pain for future research and intervention efforts.

\section{MATERIALS AND METHODS \\ The National Health Interview Survey Occupational Health Supplement}

The National Health Interview Survey (NHIS) is a personal interview survey conducted on a probability sample of civilian non-institutionalised population living in dwellings with addresses across the United States. Because the interviewees are selected through a multistage probability sampling procedure, national estimates can be generated by applying the sampling weight to the data obtained from each participant. ${ }^{18}$ Since 1957, NCHS conduct NHIS annually using a similar core questionnaire, and different supplements are added each year to study special topics. In the 1988 NHIS, the National Institute for Occupational Safety and Health (NIOSH) and the Bureau of Labor Statistics (BLS) co-sponsored an Occupational Health Supplement (NHIS-OHS) to study certain occupational diseases and conditions, including back pain.

In the 1988 NHIS, one member 18 years of age or older was randomly selected from each family in each participating household (some households had more than one family) to receive an interview with the NHIS-OHS. No proxy respondents were accepted. Official documentation with detailed information on the survey is available from $\mathrm{NCHS},{ }^{19}$ and reports of previous analyses also contain extensive description of selected features. ${ }^{16}{ }^{17}$

Abbreviations: Al, accident or injury; BLS, Bureau of Labor Statistics; BOC, Bureau of Census; NCHS, National Center for Health Statistics; NHIS, National Health Interview Survey; NIOSH, National Institute for Occupational Safety and Health; OHS, Occupational Health Supplement; RA, repeated activities; RBTR, repeated bending, twisting, or reaching; RSPA, repeated strenuous physical activities 
Main messages

- The prevalence of back pain increased as the number of working hours spent on repeated strenuous physical activities (RSPA) and the time spent on repeated bending, twisting, or reaching (RBTR) increased.

- The dose-response relations between RSPA and back pain and between RBTR and back pain were not linear.

- The estimated overall prevalence of back pain owing to repeated activities at work (RA back pain) was $8.9 \%$ (SE $0.3 \%$ ) among male workers and $5.9 \%$ (SE $0.2 \%$ ) among female workers.

- "Carpenters" had the highest prevalence (19.2\%) and most cases (338 000) of RA back pain among the major occupations of men, and "nursing aides, orderlies, and attendants" had the highest prevalence $(15.2 \%)$ and most cases $(217000)$ among the major occupations of women.

- Among the workers whose jobs involved RBTR, about one third spend almost all their working hours on such activities.

\section{Definitions of cases}

A "worker" was defined as a respondent who worked at a job or business, not counting work around the house, at any time during the past 12 months. Those who engaged in unpaid work in the family business or farm were included. Workers were then asked to give further information on their job, including the time spent on repeated strenuous physical activities (RSPA; such as lifting, pushing, or pulling heavy objects) and the time spent on repeated bending, twisting, or reaching (RBTR) on a typical workday.

A case of back pain was defined as a worker who had back pain every day for a week or more during the past 12 months, excluding menstrual back pain for women under 50 years of age. Each case was then asked to report the cause of their back pain. Those who attributed their back pain to repeated activities (RA) or a single accident or injury (AI) were asked to recall whether they performed RA or had the AI at work.

A case of work related back pain owing to RA (RA back pain) was defined as a case who reported RA as the cause of back pain and recalled performing RA at work. A case of work related back pain owing to an AI (AI back pain) was defined as a case who reported an AI as the cause of back pain and recalled having the AI at work. Because cases were allowed to

\section{Policy implications}

- Back pain related to repeated motions and bending, twisting, and reaching in the work place is prevalent among workers.

- Measures should be taken to reduce repeated motions as well as bending, twisting, and reaching in the work place to reduce back pain among workers.

- Nationwide surveys should be conducted periodically to identify occupations and industries at high risk of causing back pain so that strategies for prevention and intervention can be developed.

report both RA and an AI as the causes of back pain, they were further categorised as cases of "RA only back pain" (cases of RA back pain who did not report an AI as a cause of back pain) and cases of "AI only back pain" (cases of AI back pain who did not report RA as a cause of back pain).

\section{Definitions of occupational groups}

In the Work History section of the NHIS-OHS, respondents were also asked to give information on their jobs, and the occupations were coded with the three digit 1980 Bureau of Census (BOC) occupation and industry codes. ${ }^{20}$ In the identification of high risk occupations, the analyses only included major occupations in order to ensure that estimates were based on sufficient observations and were thus relatively stable. A "major occupation" was defined as an occupation group with a specific three digit BOC code in which more than $0.5 \%$ of the total working population of either gender were employed. Among the 502 occupation categories with specific BOC three digit codes, 49 were identified as major occupations for men (each had more than 349000 male workers), and 45 for women (each had more than 290000 female workers). For convenience, these occupation categories are referred to as "occupations" in this paper.

Cases of all categories of work related back pain as defined previously were further asked to report the jobs at which the RA were performed or, in the cases of AI back pain and AI only back pain, the jobs at which the AI occurred. The jobs were also coded by the three digit BOC codes. For a given case, the job at which the RA were performed or the AI occurred might be different from the job that the case had in the study period.

Table 1 Average time spent on repeated strenuous physical activities and repeated bending, twisting, or reaching at work on a typical workday, by gender, age, and back pain status, the USA, 1988

\begin{tabular}{|c|c|c|c|c|}
\hline \multirow[b]{2}{*}{ Attributes } & \multicolumn{2}{|c|}{ Strenuous physical activities } & \multicolumn{2}{|c|}{ Bending, twisting, or reaching } \\
\hline & $\begin{array}{l}\text { Males } \\
\text { Minutes } \\
\text { (SE) }\end{array}$ & $\begin{array}{l}\text { Females } \\
\text { Minutes } \\
\text { (SE) }\end{array}$ & $\begin{array}{l}\text { Males } \\
\text { Minutes } \\
\text { (SE) }\end{array}$ & $\begin{array}{l}\text { Females } \\
\text { Minutes } \\
\text { (SE) }\end{array}$ \\
\hline All workers & $132(3)$ & $62(2)$ & $197(3)$ & $133(3)$ \\
\hline $18-24$ years & $169(6)$ & 67 (4) & $244(6)$ & $155(6)$ \\
\hline $25-34$ years & $146(5)$ & $63(3)$ & $213(5)$ & 133 (4) \\
\hline $35-44$ years & $121(5)$ & $60(4)$ & $176(5)$ & $121(5)$ \\
\hline $45-54$ years & $107(5)$ & $62(5)$ & $173(6)$ & $132(7)$ \\
\hline $55-64$ years & 118 (7) & $65(6)$ & $182(7)$ & 137 (8) \\
\hline$>64$ years & 77 (9) & $41(7)$ & $128(11)$ & $104(11)$ \\
\hline \multicolumn{5}{|l|}{ Cases of back pain } \\
\hline All back pain & $177(6)$ & $91(4)$ & $250(6)$ & $180(5)$ \\
\hline $18-24$ years & $219(18)$ & 99 (11) & $314(15)$ & $200(15)$ \\
\hline $25-34$ years & 203 (11) & $86(7)$ & $268(11)$ & 190 (9) \\
\hline $35-44$ years & $171(10)$ & $93(8)$ & 231 (11) & $170(9)$ \\
\hline $45-54$ years & 155 (12) & $84(11)$ & 238 (14) & 148 (12) \\
\hline $55-64$ years & $141(16)$ & 96 (15) & $226(18)$ & $196(17)$ \\
\hline$>64$ years & 82 (20) & $100(29)$ & $162(29)$ & 199 (45) \\
\hline RA back pain & $260(9)$ & $168(8)$ & $341(8)$ & 292 (9) \\
\hline RA only back pain & 274 (11) & $163(10)$ & $350(10)$ & $291(12)$ \\
\hline Al only back pain & 171 (19) & $142(23)$ & $222(21)$ & $215(26)$ \\
\hline
\end{tabular}


Table 2 Prevalence and all back pain and work related back pain due to repeated activities (RA back pain) by gender, age, and work activities, the USA, 1988

\begin{tabular}{|c|c|c|c|c|c|c|c|c|c|c|}
\hline \multirow[b]{3}{*}{ Attributes } & \multicolumn{2}{|c|}{ Workers $(n=1000)^{*}$} & \multicolumn{8}{|c|}{ Prevalence of back pain } \\
\hline & \multirow[b]{2}{*}{ Males } & \multirow[b]{2}{*}{ Females } & \multicolumn{4}{|c|}{ All back pain } & \multicolumn{4}{|c|}{ RA back pain } \\
\hline & & & \multicolumn{2}{|c|}{$\begin{array}{l}\text { Males } \\
\% \text { (SE) }\end{array}$} & \multicolumn{2}{|c|}{$\begin{array}{l}\text { Females } \\
\% \text { (SE) }\end{array}$} & \multicolumn{2}{|c|}{$\begin{array}{l}\text { Males } \\
\% \text { (SE) }\end{array}$} & \multicolumn{2}{|c|}{$\begin{array}{l}\text { Females } \\
\% \text { (SE) }\end{array}$} \\
\hline \multicolumn{11}{|l|}{ Age } \\
\hline $18-24$ years & 11098 & 10548 & 13.6 & $(0.9)$ & 14.0 & (0.8) & 7.6 & (0.8) & 4.3 & (0.5) \\
\hline $25-34$ years & 19767 & 16420 & 18.1 & $(0.6)$ & 17.1 & $(0.7)$ & 9.6 & $(0.5)$ & 6.4 & (0.4) \\
\hline $35-44$ years & 16235 & 13935 & 22.0 & $(0.8)$ & 18.7 & (0.7) & 10.7 & $(0.6)$ & 6.2 & (0.5) \\
\hline $45-54$ years & 10643 & 8683 & 19.8 & $(0.9)$ & 19.5 & (1.0) & 8.4 & $(0.6)$ & 6.8 & $(0.6)$ \\
\hline $55-64$ years & 7305 & 5737 & 17.8 & $(1.2)$ & 18.2 & (1.1) & 7.3 & $(0.8)$ & 6.2 & (0.7) \\
\hline $\begin{array}{l}>64 \text { years } \\
\mathrm{p} \text { (among age groups) }\end{array}$ & 2358 & 1886 & $\begin{array}{l}17.9 \\
<0.01\end{array}$ & $(1.7)$ & $\begin{array}{l}13.9 \\
<0.01\end{array}$ & (1.6) & $\begin{array}{ll} & 3.4 \\
< & 0.01\end{array}$ & $(0.7)$ & $\begin{array}{c}2.1 \\
<0.01\end{array}$ & (0.7) \\
\hline \multicolumn{11}{|c|}{ Hours spent on repeated strenuous activities at work on a typical workday } \\
\hline No & 40437 & 43852 & 14.8 & $(0.4)$ & 15.2 & (0.4) & 4.1 & (0.3) & 3.3 & (0.2) \\
\hline $\begin{array}{l}\text { Yest } \\
P \text { (yes } v \text { no) }\end{array}$ & 26935 & 13421 & $\begin{array}{l}24.2 \\
<0.01\end{array}$ & $(0.7)$ & $\begin{array}{l}24.1 \\
<0.01\end{array}$ & $(0.9)$ & $\begin{array}{l}16.4 \\
<0.01\end{array}$ & $(0.6)$ & $\begin{array}{l}14.7 \\
<0.01\end{array}$ & (0.7) \\
\hline$<2$ hours & 8369 & 5836 & 21.6 & $(1.1)$ & 21.3 & (1.4) & 12.4 & (0.9) & 11.7 & (1.1) \\
\hline $2-4$ hours & 4787 & 2515 & 24.8 & $(1.6)$ & 24.0 & (2.0) & 17.1 & (1.3) & 16.7 & (1.9) \\
\hline 4-6 hours & 3676 & 1474 & 25.3 & (1.7) & 27.8 & (3.0) & 17.8 & $(1.6)$ & 18.0 & (2.4) \\
\hline $6-8$ hours & 6270 & 2358 & 25.8 & $(1.4)$ & 25.9 & $(2.2)$ & 19.0 & $(1.2)$ & 17.5 & (1.8) \\
\hline$>8$ hours & 1993 & 441 & 30.0 & $(2.6)$ & 39.4 & (5.5) & 24.4 & $(2.6)$ & 24.9 & (4.5) \\
\hline p (among groups) & & & $<0.00$ & & $<0.00$ & & $<0.00$ & & $<0.001$ & \\
\hline \multicolumn{11}{|c|}{ Hours spent on repeated bending, twisting, and reaching at work on a typical workday } \\
\hline No & 32731 & 34174 & 13.7 & $(0.5)$ & 13.9 & (0.4) & 3.0 & (0.3) & 2.1 & (0.2) \\
\hline Yest & 34781 & 23114 & 23.0 & $(0.6)$ & 22.3 & $(0.6)$ & 14.6 & (0.5) & 11.8 & (0.5) \\
\hline$P(y e s \vee$ no) & & & $<0.01$ & & $<0.01$ & & $<0.01$ & & $<0.01$ & \\
\hline$<2$ hours & 6411 & 6035 & 20.9 & $(1.4)$ & 19.3 & (1.1) & 9.8 & $(0.9)$ & 7.8 & (0.8) \\
\hline $2-4$ hours & 6207 & 4729 & 23.4 & $(1.3)$ & 20.4 & (1.3) & 14.0 & (1.1) & 10.4 & (1.0) \\
\hline 4-6 hours & 5431 & 3794 & 20.3 & $(1.2)$ & 23.4 & (1.5) & 13.8 & (1.0) & 13.7 & (1.3) \\
\hline $6-8$ hours & 11519 & 6341 & 24.3 & $(0.9)$ & 25.9 & (1.2) & 17.1 & $(0.9)$ & 15.3 & (1.0) \\
\hline$>8$ hours & 2867 & 858 & 29.8 & $(2.1)$ & 27.5 & (3.1) & 20.9 & $(1.9)$ & 17.1 & (2.7) \\
\hline p (among groups) & & & $<0.01$ & & $<0.01$ & & $<0.01$ & & $<0.01$ & \\
\hline
\end{tabular}

\section{Study sample and data analysis}

According to the definition described above, 30074 respondents were identified as workers, representing 127.0 million working people in the USA. A total of 5256 cases of back pain by our definition were identified, which projected to a total of about 12.5 million male and 9.9 million female cases. ${ }^{16}$

To estimate the prevalence of a given type of work related back pain, a ratio was calculated with the number of cases relating their back pain to that occupation as the numerator, and the total number of workers in a given occupation as the denominator. The total number of workers in an occupation was estimated using the data gathered through the Work History section, and the number of cases in that occupation was estimated on the basis of the information obtained trough the Back Pain section. ${ }^{18}$ The 15 major occupations with the highest prevalence were defined as "high risk occupations".

The Software for Survey Data Analyses (SUDAAN), which was designed to analyse data from complex multistage surveys ${ }^{21}$ was used for data analyses. In accordance with the practice of NCHS, ${ }^{22}$ this paper reports estimated statistics for the US population obtained by applying a weighting factor to each respondent, not the crude survey results directly. The weighting factor was chosen on the basis of the sampling frame.

\section{RESULTS}

Time spent on repeated activities on a typical workday Of the 30074 workers, 29507 answered the question on whether they spent time on RSPA at work, and 28903 gave an estimate of the time spent on a typical workday. Overall, more male workers (39.9\%, SE $0.6 \%$ ) spent time on RSPA at work than female workers $(23.5 \%$, SE $0.5 \%)$ ( $p<0.01$ for $\chi^{2}$ test for the difference). On average (including those who did no RSPA at work), male workers spent 132 (SE 3) minutes on RSPA on a typical workday, more than female workers, who spent 62 (SE 2) $\mathrm{min} /$ day $(\mathrm{p}<0.01$ for two sample test for the difference). Whereas the average time spent on RSPA by men varied across the age groups, women of different ages spent about the same amount of time (table 1). When workers were divided into six groups by two-hour intervals of the time spent on RSPA at work on a typical workday, in both genders, the ">8 hours" group had the least, and the " $<2$ hours" group had the most workers who spent time on RSPA (table 2). Male back pain cases spent an average of 177 (SE 6) min/day, and female cases spent 9l (SE 4) min/day; both were above the overall average. Cases of RA back pain spent even more time: 260 (SE 9) $\mathrm{min} /$ day by males, and 168 (SE 8) min/day by females. Male cases of AI only back pain spent about the same amount of time as back pain cases in general, but female cases of AI only back pain spent more time on RSPA than back pain cases in general (table 1).

A total of 29493 workers answered the question on whether they spent time on RBTR at work, and 28650 gave an estimate of the time spent on a typical workday. These data indicated that more male workers $(51.6 \%$, SE $0.6 \%)$ spent time on RBTR at work than female workers $(40.4 \%$, SE $0.5 \%)$ ( $p<0.01$ for $\chi^{2}$ test for the difference). The overall (including those who did not spend any time) average time spent was 197 (SE 3) min/day among men and 133 (SE 3) min/day among women ( $p<0.01$ for two sample test for the difference). As in the cases of RSPA, whereas the average time spent on RBTR by men varied across the age groups, women of different ages spent similar amounts of time (table 1). In both genders, the ">8 hours" group had the least, and the "6-8 hours" group had the most workers who spent time on RBTR at work (table $2)$. Cases of back pain also spent more time than average on RBTR: 250 (SE 6) min/day for males, and 180 (SE 5) min/day for females. Again, cases of RA back pain spent even more 
Table 3 Top 15 major occupations* requiring the most time on repeated strenuous physical activities at work on a typical workday, the USA, 1988

\begin{tabular}{|c|c|c|c|}
\hline \multirow[b]{2}{*}{ Occupation (Bureau of Census code) } & \multirow{2}{*}{$\begin{array}{l}\text { Time required } \\
\text { Minutes (SE) }\end{array}$} & \multicolumn{2}{|l|}{ Risk ranking } \\
\hline & & RA back pain $\dagger$ & Al back pain $\ddagger$ \\
\hline \multicolumn{4}{|l|}{ Male workers } \\
\hline Construction labourers (869) & $365(23)$ & 7 & 1 \\
\hline Farmers, except horticultural (473) & $360(23)$ & 9 & 11 \\
\hline Freight, stock, and material handlers, n.e.c.§ (883) & $355(28)$ & 17 & 10 \\
\hline Carpenters (567) & $307(12)$ & 1 & 6 \\
\hline Groundskeepers, and gardeners, except farm (486) & $293(32)$ & 16 & 7 \\
\hline Farm workers (479) & $277(30)$ & 18 & 4 \\
\hline Labourers, except construction (889) & $270(18)$ & 11 & 16 \\
\hline Plumbers, pipefitters, and steamfitters (585) & $263(21)$ & 4 & 14 \\
\hline Welders and cutters (738) & $261(26)$ & 12 & 17 \\
\hline Stock handlers and baggers (877) & $234(36)$ & 3 & 33 \\
\hline Printing machine operators (734) & $229(110)$ & 27 & 24 \\
\hline Automobile mechanics (505) & $228(24)$ & 2 & 20 \\
\hline Supervisors, n.e.c. (558) & $211(24)$ & 4 & 19 \\
\hline Machine operators, n.e.c. (779) & $210(29)$ & 24 & 22 \\
\hline Truck drivers, heavy (804) & 205 (13) & 13 & 2 \\
\hline \multicolumn{4}{|l|}{ Female workers } \\
\hline Nursing aides, orderlies, and attendants (447) & $212(14)$ & 1 & 1 \\
\hline Maids and housemen (449) & $204(28)$ & 5 & 2 \\
\hline Farmers, except horticultural (473) & $192(42)$ & 21 & 8 \\
\hline Labourers, except construction (889) & $166(29)$ & 6 & 5 \\
\hline Miscellaneous food preparation occupations (444) & $160(27)$ & 23 & 19 \\
\hline Licensed practical nurses (207) & $136(17)$ & 2 & 4 \\
\hline Assemblers (785) & $131(25)$ & 17 & 15 \\
\hline Cooks, except short order (436) & $130(15)$ & 13 & 11 \\
\hline Janitors and cleaners (453) & $130(15)$ & 4 & 12 \\
\hline Waiters and waitresses (435) & $123(12)$ & 9 & 14 \\
\hline Registered nurses (095) & $123(10)$ & 11 & 6 \\
\hline Textile sewing machine operators (744) & $110(22)$ & 10 & 28 \\
\hline Production inspectors, checkers, and examiners (796) & $96(28)$ & 12 & 3 \\
\hline Private household cleaners and servants (407) & $88(20)$ & 18 & 21 \\
\hline Child care workers, except private (468) & $76(14)$ & 23 & 22 \\
\hline \multicolumn{4}{|c|}{$\begin{array}{l}\text { *Major occupations were defined as occupations with more than } 349000 \text { male workers or } 290000 \text { female } \\
\text { workers. } \\
\text { †Back pain caused by repeated activities. } \\
\ddagger \text { ¿ack pain caused by a single accident or injury. } \\
\S \text { Not elsewhere classified. }\end{array}$} \\
\hline
\end{tabular}

time: 341 (SE 8) min/day for males, and 292 (SE 9) min/day for females. Whereas male cases of AI only back pain spent less time on RBTR than back pain cases in general, female cases of AI only back pain spent more time on RBTR than back pain cases in general (table 1).

Among the major occupations of men, "construction labourers" required the most time on RSPA (365 min/day), and "carpenters" required the most time on RBTR (419 min/day). Among the major occupations of women, "nursing aides, orderlies, and attendants" required the most time on RSPA ( $212 \mathrm{~min} /$ day), and "maids and housemen" required the most time on RBTR (350 min/day) (tables 3 and 4).

\section{Prevalence of back pain}

Among the seven age groups, male workers between 35 and 44 years old and female workers between 45 and 54 years old had the highest prevalence of all categories of back pain (tables 2 and 5). Workers in the youngest and the oldest groups generally had lower risks. Except for AI only back pain among women, the differences in prevalence among the age groups were statistically significant $\left(p<0.05\right.$ for $\chi^{2}$ tests for the differences). Workers who spent time on either RSPA or RBTR at work had higher prevalence of all categories of back pain than those who did not $\left(p<0.05\right.$ for all $\chi^{2}$ tests for the differences) (tables 2 and 5 ). When workers were divided into six groups by two hour intervals of the time spent on those activities at work on a typical workday, the analyses showed that the prevalence of all categories of back pain generally increased as the number of hours spent on these two types of activities increased ( $p<0.05$ for $\chi^{2}$ tests for the differences), except for AI only back pain (tables 2 and 5). For all kinds of back pain except for AI only back pain, $\chi^{2}$ tests for trend generally showed a statistically significant trend. Nonetheless, the dose-response relation was not entirely linear. For example, female workers spending 6-8 hours on RSPA had lower prevalence of RA back pain and all back pain combined than those who spent 4-6 hours, and male workers spending 4-6 hours on RBTR had lower prevalence of RA back pain and all back pain combined than those who spent 2-4 hours.

The estimated overall prevalence of RA back pain was $8.9 \%$ (SE $0.3 \%$ ) among male workers and 5.9\% (SE 0.2\%) among female workers. "Carpenters" had the highest prevalence (19.2\%) and most cases (338000) among the major occupations of men, and "nursing aides, orderlies, and attendants" had the highest prevalence (15.2\%) and most cases (217 000) among the major occupations of women (table 6). For both genders, "labourers, except construction" ranked among the high risk occupations for RA back pain. Nonetheless, workers of different genders in the same occupation may have very different risks of RA back pain. For example, in "janitors and cleaners", women had a prevalence of $12.4 \%$ (ranked fourth among the major occupations), but the prevalence among men was $9.8 \%$ (ranked twenty first).

For both men and women, 10 of the top 15 major occupations requiring most time on RSPA were high risk occupations for RA back pain (tables 3 and 6). Likewise, most (nine for men and 11 for women) of the top 15 major occupations requiring most time on RBTR were high risk occupations 
Table 4 Top 15 major occupations* requiring the most time on repeated bending, twisting, and reaching at work on a typical workday, the USA, 1988

\begin{tabular}{|c|c|c|c|}
\hline \multirow[b]{2}{*}{ Occupation (Bureau of Census code) } & \multirow{2}{*}{$\begin{array}{l}\text { Time required } \\
\text { Minutes (SE) }\end{array}$} & \multicolumn{2}{|l|}{ Risk ranking } \\
\hline & & RA back pain $\dagger$ & Al back pain $\ddagger$ \\
\hline \multicolumn{4}{|l|}{ Male workers } \\
\hline Carpenters (567) & $419(12)$ & 1 & 6 \\
\hline Construction labourers (869) & $408(22)$ & 7 & 1 \\
\hline Automobile mechanics (505) & $403(20)$ & 2 & 20 \\
\hline Welders and cutters (783) & $386(22)$ & 12 & 17 \\
\hline Freight, stock, and material handlers, n.e.c.§ (883) & $382(28)$ & 17 & 10 \\
\hline Farmers, except horticultural (473) & 381 (19) & 8 & 11 \\
\hline Farm workers (479) & 378 (29) & 17 & 4 \\
\hline Assemblers (785) & $376(31)$ & 15 & 12 \\
\hline Machine operators, n.e.c. (779) & $368(25)$ & 24 & 22 \\
\hline Plumbers, pipefitters, and steamfitters (585) & $358(25)$ & 4 & 14 \\
\hline Groundskeepers, and gardeners, except farm (486) & $343(32)$ & 16 & 7 \\
\hline Labourers, except construction (889) & $340(20)$ & 11 & 16 \\
\hline Painters, construction and maintenance (579) & $339(36)$ & 19 & 21 \\
\hline Stock handlers and baggers (877) & $331(40)$ & 3 & 33 \\
\hline Electricians (575) & $320(20)$ & 23 & 3 \\
\hline \multicolumn{4}{|l|}{ Female workers } \\
\hline Maids and housemen (449) & $350(27)$ & 5 & 2 \\
\hline Labourers, except construction (889) & 340 (33) & 6 & 5 \\
\hline Nursing aides, orderlies, and attendants (447) & 284 (13) & 1 & 1 \\
\hline Assemblers (785) & $280(30)$ & 17 & 15 \\
\hline Farmers, except horticultural (473) & $269(60)$ & 21 & 8 \\
\hline Janitors and cleaners (453) & $266(17)$ & 4 & 12 \\
\hline Cooks, except short order (436) & 245 (18) & 13 & 11 \\
\hline Waiters and waitresses (435) & $232(15)$ & 9 & 14 \\
\hline Licensed practical nurses (207) & $230(22)$ & 2 & 4 \\
\hline Hairdressers and cosmetologists (458) & $215(19)$ & 3 & $45 \pi$ \\
\hline Textile sewing machine operators (744) & $208(27)$ & 9 & 28 \\
\hline Private household cleaners and servants (407) & $206(20)$ & 18 & 21 \\
\hline Registered nurses (095) & $201(14)$ & 11 & 6 \\
\hline Child care workers, except private (468) & $199(19)$ & 28 & 22 \\
\hline Cashiers (276) & $193(11)$ & 14 & 26 \\
\hline \multicolumn{4}{|c|}{$\begin{array}{l}\text { *Major occupations were defined as occupations with more than } 349000 \text { male workers or } 290000 \text { female } \\
\text { workers. } \\
\text { †Work related back pain caused by repeated activities at work. } \\
\text { †Work related back pain caused by a single accident or injury at work. } \\
\S \text { Not elsewhere classified. } \\
\text { \No cases of back pain caused by a single accident or injury were observed among workers in seven major } \\
\text { occupations for women, which included "hairdressers and cosmetologists". }\end{array}$} \\
\hline
\end{tabular}

for RA back pain (tables 4 and 6). In both genders, many of the top 15 major occupations requiring most time on RSPA or RBTR were also high risk major occupations of AI back pain (tables 3, 4, and 7).

\section{DISCUSSION}

\section{Time spent on repeated activities at work}

In the literature, data on the time spent on a specific activity by workers of different occupation are quite limited, and therefore data from the NHIS-OHS are unique and valuable. Workers of different genders in the same occupation may have very different work activities. For example, although male and female workers in "cashiers" spent almost the same amount of time on RSPA ( $73 \mathrm{~min} /$ day and $75 \mathrm{~min} /$ day respectively), females spent much more time on RBTR (193 $\mathrm{min} /$ day versus $150 \mathrm{~min} /$ day). In contrast, male and female workers in "labourers, except construction" spent the same amount of time on RBTR ( $340 \mathrm{~min} /$ day), but men spent much more time on RSPA ( $270 \mathrm{~min} /$ day versus $166 \mathrm{~min} /$ day). Of course, the time spent on those types of activities can be very different as in the case of "janitors and cleaners" described previously.

\section{Association between repeated activities and back pain}

Many studies observed associations between heavy physical work and back pain. ${ }^{23-31}$ However, data on effects of RSPA were very limited, especially those on the dose-response relations. A study by Chaffin and Park ${ }^{23}$ failed to find a dose-response correlation between the frequency of lifting and prevalence of back pain. Likewise, data on the specific effects of RBTR were also very limited, especially those on the dose-response relation. A study by Riihimki and colleagues ${ }^{32}$ observed a dose-response correlation between sciatic pain and bending or twisting.

The NHIS-OHS data supported the association between RSPA and back pain as well as that between RBTR and back pain. Workers who performed such activities at work had a higher prevalence than those who did not. In general, the prevalence of back pain increased as the time spent on those activities increased, except for AI only back pain, which was not surprising, because those activities were not regarded as being related to such back pain.

The dose-response relations observed for RSPA, however, were not linear. One of the possible reasons for the non-linear relation is that the actual frequency of body motion and workload were not taken into consideration. Obviously, an ordinary worker cannot perform heavy work with high repetitive frequency for a prolonged period of time. Therefore, it was not surprising that prevalence did not vary much from the second to the fourth group by two hour intervals (table 2 ). The last group ( $>8$ hours) had a much higher prevalence than the fourth group, which might partially be attributable to the fact that workers in this group work overtime (more than eight hours a day). The dose-response relations between RBTR and back pain were even more complicated. Although the same explanations can be applied, more factors might affect the relations. 
Table 5 Prevalence of work related back pain due to repeated activities only (RA only back pain), work related back pain due to a single accident or injury only (AI only back pain), and work related back pain due to an accident or injury (Al back pain), by gender, age, and work activities, the USA, 1988

\begin{tabular}{|c|c|c|c|c|c|c|}
\hline \multirow[b]{3}{*}{ Attributes } & \multicolumn{6}{|c|}{ Prevalence of back pain } \\
\hline & \multicolumn{2}{|c|}{ RA only back pain } & \multicolumn{2}{|c|}{ Al only back pain } & \multicolumn{2}{|c|}{ Al back pain } \\
\hline & $\begin{array}{l}\text { Males } \\
\% \text { (SE) }\end{array}$ & $\begin{array}{l}\text { Females } \\
\% \text { (SE) }\end{array}$ & $\begin{array}{l}\text { Males } \\
\% \text { (SE) }\end{array}$ & $\begin{array}{l}\text { Females } \\
\% \text { (SE) }\end{array}$ & $\begin{array}{l}\text { Males } \\
\% \text { (SE) }\end{array}$ & $\begin{array}{l}\text { Females } \\
\% \text { (SE) }\end{array}$ \\
\hline \multicolumn{7}{|l|}{ Age } \\
\hline $18-24$ years & $4.0(0.5)$ & $3.3(0.4)$ & $0.6(0.2)$ & $0.5(0.2)$ & $4.2(0.6)$ & $1.6(0.3)$ \\
\hline $25-34$ years & $5.8(0.4)$ & $4.0(0.3)$ & $2.1 \quad(0.3)$ & $0.8(0.2)$ & $5.9(0.4)$ & $3.2(0.3)$ \\
\hline $35-44$ years & $6.3(0.4)$ & $3.8(0.4)$ & $2.1 \quad(0.2)$ & $1.1 \quad(0.2)$ & $6.5(0.4)$ & $3.5(0.4)$ \\
\hline $45-54$ years & $5.3(0.5)$ & $4.2(0.5)$ & $1.8(0.3)$ & $1.2(0.3)$ & $4.9(0.5)$ & $3.8(0.5)$ \\
\hline $55-64$ years & $4.3(0.7)$ & $4.2(0.6)$ & $2.4(0.4)$ & $0.7 \quad(0.2)$ & $5.3(0.6)$ & $2.8(0.5)$ \\
\hline$>64$ years & $2.4(0.6)$ & $1.8(0.7)$ & $2.3(0.8)$ & $1.0(0.4)$ & $3.3(0.9)$ & $1.3(0.4)$ \\
\hline p (among groups) & $<0.01$ & 0.04 & $<0.01$ & 0.15 & $<0.01$ & $<0.01$ \\
\hline \multicolumn{7}{|c|}{ Hours spent on repeated strenuous activities at work on a typical workday } \\
\hline No & $2.2(0.2)$ & $2.3(0.2)$ & $1.6(0.2)$ & $0.7(0.1)$ & $3.5(0.2)$ & $1.7(0.2)$ \\
\hline Yes* & $10.1(0.4)$ & $9.1(0.6)$ & $2.3(0.2)$ & $1.7(0.3)$ & $8.5(0.5)$ & $7.3(0.5)$ \\
\hline $\mathrm{p}($ yes $v$ no) & $<0.01$ & $<0.01$ & 0.01 & $<0.01$ & $<0.01$ & $<0.01$ \\
\hline$<2$ hours & $7.2(0.6)$ & $7.5(0.9)$ & $2.4(0.4)$ & $1.4(0.4)$ & $7.6(0.7)$ & $5.6(0.8)$ \\
\hline $2-4$ hours & $10.9(1.1)$ & $9.4(1.6)$ & $1.9(0.5)$ & $1.5(0.6)$ & $8.1(1.0)$ & $8.8(1.4)$ \\
\hline $4-6$ hours & 11.4 (1.3) & $10.6(1.9)$ & $1.6(0.5)$ & $1.5(0.9)$ & 7.9 (1.1) & 8.9 (1.7) \\
\hline $6-8$ hours & $11.1 \quad(1.0)$ & $11.6(1.5)$ & $2.6(0.5)$ & $2.4(0.8)$ & 10.5 (1.0) & $8.3(1.2)$ \\
\hline$>8$ hours & $16.5(2.1)$ & $12.3(3.0)$ & $1.7(0.6)$ & 3.2 (1.7) & $9.6(1.6)$ & $15.8(4.2)$ \\
\hline p (among groups) & $<0.01$ & $<0.01$ & 0.13 & 0.02 & $<0.01$ & $<0.01$ \\
\hline \multicolumn{7}{|c|}{ Hours spent on repeated bending, twisting, and reaching at work on a typical workday } \\
\hline No & $1.5(0.2)$ & $1.4(0.1)$ & $1.6(0.2)$ & $0.7(0.1)$ & $3.1(0.2)$ & $1.3(0.1)$ \\
\hline Yes* & $9.0(0.4)$ & $7.4(0.4)$ & $2.1(0.2)$ & $1.2(0.2)$ & $7.7(0.4)$ & $5.6(0.4)$ \\
\hline $\mathrm{p}($ yes $v$ no) & $<0.01$ & $<0.01$ & 0.05 & $<0.01$ & $<0.01$ & $<0.01$ \\
\hline$<2$ hours & $6.1(0.7)$ & $5.3(0.6)$ & $2.4(0.5)$ & $1.0(0.3)$ & $6.1 \quad(0.8)$ & $3.6(0.6)$ \\
\hline $2-4$ hours & $9.1(0.9)$ & $5.3(0.8)$ & $2.1 \quad(0.4)$ & $0.5(0.2)$ & $7.0(0.7)$ & $5.5(0.8)$ \\
\hline $4-6$ hours & $9.2(0.9)$ & $8.1 \quad(0.9)$ & $1.4(0.4)$ & $1.2(0.4)$ & $6.1 \quad(0.8)$ & 6.8 (1.0) \\
\hline $6-8$ hours & $9.7(0.7)$ & $10.6(0.9)$ & $1.9(0.3)$ & $1.9(0.4)$ & $9.4(0.7)$ & $6.6(0.7)$ \\
\hline$>8$ hours & $13.1(1.4)$ & $10.3(1.9)$ & $2.2(0.6)$ & $0.9(0.6)$ & $10.0(1.4)$ & 7.7 (2.0) \\
\hline p (among groups) & $<0.01$ & $<0.01$ & 0.27 & 0.03 & $<0.01$ & $<0.01$ \\
\hline
\end{tabular}

\section{Prevalence of back pain}

In comparison with studies using workers' compensation claims, the prevalence of back pain among workers estimated by this analysis was much higher. A study on workers' compensation claims from 26 states found that the average number of claims on back injuries was only about 0.86 per 100 workers per year. ${ }^{1}$ Data from workers' compensation tend to underestimate the risks for at least two major reasons: many people with back pain do not go to see a doctor, and many back pain patients are not awarded with workers' compensation. A study showed that about half of the people who had back pain did not seek medical care, ${ }^{33}$ and another study estimated that only about $10 \%$ of low back pain cases received workers' compensation. ${ }^{34}$ When those two factors were taken into consideration, the worker compensation data might cover only a very small portion of back pain cases.

Only a few occupations were identified as the major occupations for both genders, which indicated that male and female workers generally had different occupations. Even within the same occupation, the risk of back pain could be very different between male and female workers. The difference in work activities might be one of the reasons. For example, female and male workers in "janitors and cleaners" had very different prevalence of RA back pain. Likewise, male and female "janitors and cleaners" had very different time spent on RSPA at work ( $174 \mathrm{~min} /$ day versus $130 \mathrm{~min} /$ day) and time spent on RBTR (304 min/day versus $266 \mathrm{~min} /$ day). A similar example was "assemblers". Among male workers, the prevalence of RA back pain was $12.7 \%$, but among female workers, it was only $6.1 \%$. The average time spent on RSPA at work was $199 \mathrm{~min} /$ day among men and $131 \mathrm{~min} /$ day among women, and the average time spent on RBTR was $376 \mathrm{~min} /$ day among men and $280 \mathrm{~min} /$ day among women; as in the prevalence of back pain, both were much less among women.

\section{Strengths and limitations of the National Health Interview Survey}

In comparison with the other nationwide studies on back pain in the United States, ${ }^{13-15}$ the 1988 NHIS-OHS had the strength of using a large representative sample with minimal sampling bias. The size of the sample was large enough to provide accurate national estimates and to generate estimates on subpopulations defined by a variety of potential risk factors. For example, national estimates on a specific occupation group defined by three digit BOC codes as presented in this paper cannot be obtained by a small study population or even a large local population, such as thousands of workers in a large plants. However, the data still cannot be used to derive reliable estimates on occupations with small numbers of workers or other types of small subgroups in the population.

The validity of self reported data is a major uncertainty in the NHIS-OHS, which may affect both exposure and outcome data. The outcome of interest, back pain, is a subjective symptom that is hard to validate, because medical imaging and laboratory tests are normal in most cases. Even among people with abnormal medical imaging, the findings may not agree with the existence or severity of symptoms ${ }^{35}$ Furthermore, the existence of such a subjective symptom is hard to invalidate. On the other hand, because there was no incentive for over-reporting and no obvious reason for under-reporting, answers to the questionnaire should generally reflect the true feeling of the case, and thus the outcome measurement was mostly unbiased. Therefore, using a questionnaire as the measurement tool should not be considered a limitation of the study. Other sources of data, such as workers' compensation, might be more objective, but tend to lead to underestimation of the prevalence.

The situation with the exposure data is quite different. There are ways to make better measurements of two major 
Table 6 Top 15 high risk major occupations* for back pain attributable to repeated activities at work, the USA, 1988

\begin{tabular}{|c|c|c|}
\hline Occupation (Bureau of Census code) & Number of cases & $\begin{array}{l}\text { Prevalence } \\
\% \text { (SE) }\end{array}$ \\
\hline Male workers & 6068000 & $8.9(0.3)$ \\
\hline Carpenters (567) & 338000 & $19.2(2.2)$ \\
\hline Automobile mechanics (505) & 173000 & $17.7(3.0)$ \\
\hline Stock handlers and baggers (877) & 72000 & $17.2(4.8)$ \\
\hline Plumbers, pipefitters, and steamfitters (585) & 91000 & $16.7(4.0)$ \\
\hline Supervisors, n.e.c. $†(558)$ & 88000 & $16.6(4.1)$ \\
\hline Industrial machinery repairers (518) & 73000 & $16.0(4.5)$ \\
\hline Construction labourers (869) & 112000 & $15.9(3.7)$ \\
\hline Industrial truck and tractor equipment operators (856) & 76000 & $15.0(4.0)$ \\
\hline Farmers, except horticultural (473) & 169000 & $14.9(2.5)$ \\
\hline Miscellaneous machine operators, n.e.c. (777) & 79000 & $13.8(3.7)$ \\
\hline Laborers, except construction (889) & 159000 & $13.7(2.4)$ \\
\hline Welders and cutters (783) & 84000 & $13.4(3.3)$ \\
\hline Truck drivers, heavy (804) & 268000 & $13.1(1.9)$ \\
\hline Truck drivers, light (805) & 83000 & $13.0(3.1)$ \\
\hline Assemblers (785) & 76000 & $12.7(3.1)$ \\
\hline Female workers & 3426000 & $5.9(0.2)$ \\
\hline Nursing aides, orderlies, and attendants (447) & 217000 & $15.2(2.2)$ \\
\hline Licensed practical nurses (207) & 85000 & $13.9(3.3)$ \\
\hline Hairdressers and cosmetologists (458) & 91000 & $12.5(3.1)$ \\
\hline Janitors and cleaners (453) & 94000 & $12.4(2.8)$ \\
\hline Maids and housemen (449) & 67000 & $11.9(2.8)$ \\
\hline Labourers, except construction (889) & 40000 & $11.1(3.6)$ \\
\hline Designers (185) & 36000 & $9.3(3.0)$ \\
\hline Health aides, except nursing (446) & 32000 & $9.2(3.6)$ \\
\hline Waiters and waitresses (435) & 122000 & $9.0(1.7)$ \\
\hline Textile sewing machine operators (744) & 58000 & $8.8(2.5)$ \\
\hline Registered nurses (095) & 143000 & $8.6(1.3)$ \\
\hline Production inspectors, checkers, and examiners (796) & 31000 & $8.5(3.4)$ \\
\hline Cooks, except short order (436) & 78000 & $8.4(1.9)$ \\
\hline Cashiers (276) & 162000 & $7.4(1.3)$ \\
\hline Management related occupations, n.e.c. (037) & 22000 & $7.1(4.2)$ \\
\hline
\end{tabular}

risk factors identified in our analysis. For example, the time spent on RBTR at work on a typical workday can be measured more accurately by videotaping. Such approaches, however, are hard to apply to large scale studies.

Recall bias might occur in the survey because back pain cases might report more work activities that they thought to be the cause of their back pain than other workers. Whereas the NHIS-OHS questionnaire put the questions on exposures before the questions of outcomes, which could decrease the degree of such biases to certain levels, it could not eliminate the possibility of obtaining a biased result. This limitation is common to questionnaire surveys and needs further validation studies to evaluate its effects on the risk estimates.

As in assessing the occurrence of back pain, whether or not the back pain was work related was determined by the interviewee without validation. In fact, for a subjective symptom like back pain, whether it is related to work activities is often hard to determine. Again, since there were no incentives for over-reporting and no obvious reason for under-reporting, the answer to the questionnaire should generally reflect the actual belief of the respondent. Although this does not prevent misclassification, differential misclassification should be minimised.

Whereas two types of high risk work activities for back pain were identified by this analysis, information on other occupational risk factors was not elicited by the survey. For example, although whole body vibration ${ }^{25} 36-40$ and static work postures $^{25} 28$ 41-43 $^{4}$ have been recognised as risk factors of back pain, neither were included in the NHIS-OHS questionnaire. For the two types of high risk work activities studied, there were positive dose-response relations, but dose-response curves were not linear. The fact that the risk of back pain did not increase proportionately as the dose of a risk factor increased might result from a healthy worker survival effect ${ }^{44}$ or effects of other unmeasured risk factors. Under such circumstances, using a continuous variable to represent these risk factors in data analysis will not be able to produce accurate risk estimates. Therefore, in further studies, these factors are better analysed as categorical variables as in the present study.

By the case definition used in the NHIS-OHS questionnaire, back pain patients without any episode lasting for a week or more during the 12 month period before the interview were not counted as cases. A study showed that among those who suffered from low back pain, about one third of men and 17\% of women had low back pain for less than eight days altogether in the one year study period.$^{45}$ In addition, patients who were unable to work during the entire 12 month period were excluded by the definition of "worker" and thus were not included as cases. Therefore, although the present study has covered the majority of cases, results might not be applicable to a small part of back pain patients.

Because the case definitions used in NHIS-OHS were quite different from those used in other nationwide surveys, it is difficult to compare the results. In addition, the NHIS-OHS is conducted on a cross sectional sample for one time only, and therefore similar surveys are needed to evaluate its reliability and monitor trends of the problem over time. Furthermore, the high risk occupations might have changed since 1988, and a follow up survey is needed to obtain updated information. Nonetheless, it provides the most comprehensive data that are currently available on repeated activities performed at the workplace; the present study has generated many useful data and produced many important findings. Moreover, regarding the effects of repeated motions and bending, twisting, and reaching on back pain, the findings should be valid in spite of 
Table 7 Top 15 high risk major occupations* for back pain attributable to a single accident or injury at work, the USA, 1988

\begin{tabular}{|c|c|c|}
\hline Occupation (Bureau of Census code) & Number of cases & $\begin{array}{l}\text { Prevalence } \\
\% \text { (SE) }\end{array}$ \\
\hline Male workers & 3706000 & $4.4(0.2)$ \\
\hline Construction labourers (869) & 84000 & $11.9(3.0)$ \\
\hline Truck drivers, heavy (804) & 191000 & $9.3(1.5)$ \\
\hline Electricians (575) & 65000 & $9.3(3.2)$ \\
\hline Farm workers (479) & 53000 & $9.0(3.5)$ \\
\hline Industrial truck and tractor equipment operators (856) & 43000 & $8.6(3.6)$ \\
\hline Carpenters (567) & 148000 & $8.4(1.5)$ \\
\hline Groundskeepers, and gardeners, except farm (486) & 57000 & $8.1(3.2)$ \\
\hline Miscellaneous machine operators, n.e.c. $†$ (777) & 44000 & $7.6(3.2)$ \\
\hline Police and detectives, public service (418) & 32000 & $6.5(2.5)$ \\
\hline Freight, stock, and material handlers, n.e.c. (883) & 40000 & $6.5(2.2)$ \\
\hline Farmers, except horticultural (473) & 70000 & $6.2(1.6)$ \\
\hline Assemblers (785) & 34000 & $5.7(2.3)$ \\
\hline Truck drivers, light (805) & 36000 & $5.6(2.1)$ \\
\hline Plumbers, pipefitters, and steamfitters (585) & 31000 & $5.6(2.2)$ \\
\hline Janitors and cleaners (453) & 81000 & $5.4(1.4)$ \\
\hline Female workers & 1731000 & $2.0(0.1)$ \\
\hline Nursing aides, orderlies, and attendants (447) & 107000 & $7.5(1.7)$ \\
\hline Maids and housemen (449) & 8000 & $6.8(2.2)$ \\
\hline Production inspectors, checkers, and examiners (796) & 25000 & $6.6(3.0)$ \\
\hline Licensed practical nurses (207) & 39000 & $6.4(2.1)$ \\
\hline Labourers, except construction (889) & 22000 & $6.2(3.2)$ \\
\hline Registered nurses (095) & 88000 & $5.3(1.5)$ \\
\hline Designers (185) & 19000 & $4.9(2.4)$ \\
\hline Farmers, except horticultural (473) & 8000 & $2.8(2.1)$ \\
\hline Supervisors, general office (303) & 8000 & $2.7(2.1)$ \\
\hline Social workers (174) & 11000 & $2.7(1.5)$ \\
\hline Cooks, except short order (436) & 24000 & $2.6(1.2)$ \\
\hline Janitors and cleaners (453) & 19000 & $2.5(1.2)$ \\
\hline Supervisors and proprietors, sales occupations (243) & 32000 & $2.5(0.9)$ \\
\hline Waiters and waitresses (435) & 34000 & $2.5(0.8)$ \\
\hline Assemblers (785) & 13000 & $2.3(1.3)$ \\
\hline
\end{tabular}

the fact that the survey was done about a decade ago. The results showed that among the workers whose jobs involved RBTR, about one third spend almost all their working hours on such activities, which would put them at a high risk of developing back pain. We should note that repeated motions as well as bending, twisting, and reaching can be minimised by applying machinery and ergonomic measures in workplaces. Through analysis of data from the NHIS-OHS, high risk occupations were identified for further studies and interventions to prevent work related back pain.

\section{ACKNOWLEDGEMENTS}

The author would like to thank NIOSH for the assistance in conduct of this study. In particular, Dr Shiro Tanaka helped to set up the plan for data analysis, Dr John Sestito helped to coordinate the study, and Mrs Deanna K Wild helped with the initial analyses of the data.

\section{Author's affiliation}

H-R Guo, Graduate Institute of Environmental and Occupational Health, Medical College, National Cheng Kung University, Taiwan

\section{REFERENCES}

1 Klein BP, Jensen RC, Sanderson LM. Assessment of workers' compensation claims for back strains/sprains. J Occup Med 1984; $26: 443-8$

2 National Council on Compensation Insurance. Workers' compensation back pain claim study. New York: National Council on Compensation Insurance, 1993.

3 Labar G. A battle plan for back injury prevention. Occupational Hazards 1992;11:29-33.

4 Frymoyer JW, Cats-Baril WL. An overview of the incidence and costs of low back pain. Orthop Clin North Am 1991;22:262-71.

5 Broberg E. Ergonomic injuries at work. ISA Information System on Occupational Injuries, Report No. 1984:3E. Stockholm: Swedish National Board of Occupational Safety and Health, 1984.
6 Svane O. National prevention of musculoskeletal workplace injury: Denmark-a summary. Ergonomics 1987;30:181-4

7 Gervais M, Hebert P. Statistical summary of back injuries. Quebec: Institute de Recherche en Sante et en Securite du Travail du Quebec, 1987.

8 Abenhaim L, Suissa S. Economic scope of occupationally-induced back pain. IRSST Research Summary No. 66. Quebec: Institute de Recherche en Sante et en Securite du Travail du Quebec, 1988.

9 Burry HC, Gravis V. Compensated back injury in New Zealand. N Z Med J 1988;101:542-4.

10 Stubbs D. Ergonomics and back pain. Occup Health 1991;43:82-5.

11 Liira JP, Shannon HS, Chambers LW, et al. Long-term back problems and physical work exposures in the 1990 Ontario Health Survey. Am J Public Health 1996:86:382-7.

12 Guo H-R. Occupational low back pain. Chinese Journal of Public Health 2000; 19:332-9.

13 Leigh JP, Sheetz RM. Prevalence of back pain among fulltime United States workers. Br J Ind Med 1989:46:651-7.

14 Cunningham LS, Kelsey JL. Epidemiology of musculoskeletal impairments and associated disability. Am J Public Health 1984;74:574-9.

15 Deyo RA, Tsui-Wu Y-J. Descriptive epidemiology of low-back pain and its related medical care in the United States. Spine 1987;12:264-8.

16 Guo H-R, Tanaka S, Cameron LL, et al. Back pain among U.S. workers: national estimates and workers at high risk. Am J Ind Med 1995:28:591-602.

17 Guo H-R, Tanaka S, Halperin WE, et al. Back pain prevalence in US industry and estimates of lost workdays. Am J Public Health 1999;89: 1029-35

18 Park CH, Wagener DK, Winn DM, et al. Health conditions among the currently employed: United States, 1988. Vital and health statistics, Series 10: Data from the National Health Interview Survey, No. 186. DHHS publication no. PHS93-1514. Hayttsville: National Center for Health Statistics, 1993

19 Adams PF, Hardy AM. Current estimates from the National Health Interview Survey: United States, 1988. Vital and Health Statistics, Series 10. Data from the National Health Interview Survey, No. 173. DHHS publication no. PHS89-1501. Hayttsville: National Center for Health Statistics, 1989

20 Bureau of Census. Alphabetical index of industries and occupations, 1980 census of population, final edn. Washington, DC: US Department of Commerce, 1982. 
21 Research Triangle Institute. Software for Survey Data Analysis (SUDAAN), version 5.30. Research Triangle Park: Research Triangle Institute, 1990.

22 Massey JT, Moore TF, Parsons VL, et al. Design and estimation for the National Health Interview Survey, 1985-1994. Vital and Health Statistics, Series 2: Data evaluation and methods research, No. 110. DHHS publication PHS89-1384). Hayttsville: National Center for Health Statistics, 1989

23 Chaffin DB, Park KS. A longitudinal study of low back pain as associated with occupational weight lifting factors. Am Ind Hyg Assoc J 1973:34:513-25

24 Liles DH, Deivanayagam S, Ayoub MM, et al. A job severity index for the evaluation and control of lifting injury. Hum Factors 1984; 26:683-93.

25 Bernard BP, ed. Musculoskeletal disorders and workplace factors. Cincinnati, OH: US Department of Health and Human Services, National Institute for Occupational Safety and Health, USA, 1997.

26 Bergenudd H, Nilsson B. Back pain in middle age. Occupational workload and psychologic factors: an epidemiologic survey. Spine $1988 ; 13: 58-60$.

27 Walsh K, Varnes N, Osmond C, et al. Occupational causes of low back pain. Scand J Work Environ Health 1989;15:54-5.

28 Burdorf A, Zondervan $\mathrm{H}$. An epidemiological study of low-back pain in crane operators. Ergonomics 1990;33:981-7.

29 Heliovaara $M$, Makela M, Knekt $P$, et al. Determinants of sciatica and low back pain. Spine 1991;16:608-14.

30 Marras WS, Lavender SA, Leurgans SE, et al. The role of dynamic three-dimensional trunk motion in occupationally-related low back disorders: the effects of workplace factors, trunk position, and trunk motion characteristics on risk of injury. Spine 1993;18:617-28.

31 Marras WS, Lavender SA, Leurgans SE, et al. Biomechanical risk factors for occupationally-related low back disorders. Ergonomics 1995;38:377-410

32 Riihimki H, Tola S, Videman T, et al. Low-back pain and occupation: a cross-sectional questionnaire study of men in machine operating dynamic physical work, and sedentary work. Spine 1989;14:204-9.
33 Reishbord LS, Greenland S. Factors associated with self-reported back-pain prevalence: a population-based study. J Chron Dis 1985;38:691-702

34 Chaffin DB. Manual materials handling-the cause of over-exertion injury and illness in industry. J Environ Pathol Toxicol 1979;2:67-73.

35 Jensen MC, Brant-Zawadzki MN, Obuchowski N, et al. Magnetic resonance imaging of the lumbar spine in people without back pain. N Engl J Med 1994;331:69-73.

36 Bongers PM, Boshuizen HC, Hulshof CTJ, et al. Back pain and exposure to whole-body vibration. Int Arch Occup Environ Health 1988;60:129-37.

37 Boshuizen HC, Bongers PM, Hulshof CTJ. Self-reported back pain in fork-lift truck and freight-container tractor drivers exposed to whole-body vibration. Spine 1992:17:59-65

38 Bovenzi M, Zadini A. Self-reported low back symptoms in urban bus drivers exposed to whole-body vibration. Spine 1992;17:1048-59.

39 Bovenzi M, Betta A. Low-back disorders in agricultural tractor drivers exposed to whole-body vibration and posture stress. Appl Ergon 1994:25:231-41.

40 Wilder DG, Hope MH. Epidemiological and aetiological aspects of low back pain in vibration environments - an update. Clin Biomechanics 1996;11:61-73.

41 Svensson $\mathbf{H}$, Andersson GBJ. The relationship of low-back pain, work history and work environment, and stress: a retrospective cross-sectional study of 38- to 64-year old women. Spine 1989;14:517-22.

42 Videman T, Nurminen M, Troup JDG. Lumbar spine pathology in cadaveric material in relation to history of back pain, occupation, and physical loading. Spine 1990;15:728-40.

43 Skov T, Brog V, Orhede E. Psychosocial and physical risk factors for musculoskeletal disorders of the neck, shoulders, and lower back in sales people. Occup Environ Med 1996;53:351-6.

44 Choi BCK. Definitions, sources, magnitude, effect modifiers, and strategies of reduction of the healthy worker effect [the author replies]. J Occup Med 1993;35:890-1.

45 Biering-Sorensen $\mathbf{F}$. A prospective study of low-back pain in a general population. I. Occurrence, recurrence, and etiology. Scand J Rehabil Med 1983:15:81-8.

\section{OEM web submission and review system}

I am pleased to inform authors and reviewers of the new online submission and review system at OEM. Developed by Highwire Press (CA, USA), Bench>Press is a fully integrated electronic system which uses the internet to allow rapid and efficient submission of manuscripts. It also allows the peer review process to be conducted entirely online. The main aim is to speed up the frequently frustrating progress from submission to publication.

Authors can submit their manuscript in any standard word processing software. Standard graphic formats accepted include: .jpg, .tiff, .gif, eps, etc. (Please note: multi page powerpoint files are not accepted by the BM Publishing Group.) The text and graphic files are automatically converted to PDF for ease of distribution and reviewing purposes. Authors are asked to approve their submission before it formally enters the reviewing process. On approval, the submission is passed to the editor and/or reviewers via the web. All transactions are secure.

To access the system click on "SUBMIT YOUR MANUSCRIPT HERE" on the OEM homepage: http://www.occenvmed.com, or you can access the submission site directly at http://submitoem.bmijournals.com.

We are very excited with this new development and would encourage authors and reviewers to use the system where possible. It really is simple to use and should greatly improve on the current peer review process. Full instructions can be found on Bench>Press http://submitoem.bmijournals.com and OEM online at http://www.occenvmed.com. Please contact Natalie Davies, Project Manager, ndavies@bmigroup.com

Anne Cockcroft 